\title{
Investigating the synergistic effect of UV/PS/TiO2 and UV/PI/TiO2 processes on paraquat herbicide degradation in media aqueous: statistical optimization, kinetic study, and estimation of electrical energy consumption
}

Azam Ghavi ( $\square$ azamghavi@ymail.com )

Shahrood University of Technology

Ghadamali Bagherian

Shahrood University of Technology

Hadi Rezaei Vahidian

Iranian Space Agency

\section{Research Article}

Keywords: Hybrid advanced oxidation processes, Periodate and Persulfate oxidations, Paraquat herbicide degradation, Response surface methodology, Central Composite Design (CCD), Kinetic study.

Posted Date: February 26th, 2021

DOl: https://doi.org/10.21203/rs.3.rs-277799/v1

License: (9) This work is licensed under a Creative Commons Attribution 4.0 International License. Read Full License 


\title{
Investigating the synergistic effect of $\mathrm{UV} / \mathrm{PS} / \mathrm{TiO}_{2}$ and \\ $\mathrm{UV} / \mathrm{PI} / \mathrm{TiO}_{2}$ processes on paraquat herbicide degradation in media aqueous: statistical optimization, kinetic study, and estimation of electrical energy consumption
}

\author{
Azam Ghavi ${ }^{{ }^{*}}$, Ghadamali Bagherian ${ }^{\text {a }}$, Hadi Rezaei Vahidian ${ }^{\mathrm{b}}$ \\ a Faculty of Chemistry, Shahrood University of Technology, P.O. Box 316-3619995181, Shahrood, \\ Iran \\ b Space transportation research institute, Iranian space research center, Tehran, Iran. \\ *Corresponding author: azamghavi@ymail.com
}

Research Laboratory of Faculty Chemistry, Shahrood University of Technology, P.O. Box 316-3619995181, Shahrood, Iran

\begin{abstract}
In this paper, the performance of $\mathrm{UV} / \mathrm{PS} / \mathrm{TiO}_{2}$ and $\mathrm{UV} / \mathrm{PI} / \mathrm{TiO}_{2}$ as hybrid $\mathrm{AOPs}$ for degradation of paraquat (PQ) herbicide in aqueous solution has been studied. The effect of several factors such as UV irradiation, initial oxidant concentration, nano- $\mathrm{TiO}_{2}\left(\mathrm{TiO}_{2} \mathrm{NPs}\right)$ dosage, and $\mathrm{pH}$ on the degradation efficiency was investigated. Process optimization was performed by Central Composite Design (CCD) and response surface methodology (RSM) for $30 \mathrm{mgL}^{-1}$ of herbicide at $25{ }^{\circ} \mathrm{C}$ and $40 \mathrm{~min}$. Based on the results, for UV/PS/TiO 2 process a degradation efficiency of $83 \%$ was obtained in the optimum condition of initial PS

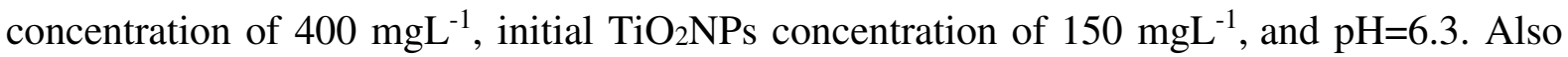
for $\mathrm{UV} / \mathrm{PI} / \mathrm{TiO}_{2}$ process, $87 \%$ degradation efficiency was achieved in the optimum condition of initial PI concentration of $88 \mathrm{mgL}^{-1}$, initial $\mathrm{TiO}_{2} \mathrm{NPs}$ dosage of $125.5 \mathrm{mgL}^{-1}$, and $\mathrm{pH}$ of 7.5. Mineralization efficiency of the PQ solution by using PS and PI were about $47.5 \%$ and $57 \%$, respectively after $80 \mathrm{~min}$. Kinetic studies showed that both process follow pseudo-first-order
\end{abstract}


kinetic model and their kinetic constants were $0.0299 \mathrm{~min}^{-1}$ for PS process and $0.0604 \mathrm{~min}^{-1}$ for PI process. Electrical energy consumption was estimated about $481.60 \mathrm{kWh} / \mathrm{m}^{3}$ for PS process and $238.41 \mathrm{kWh} / \mathrm{m}^{3}$ for PI process.

Keyword: Hybrid advanced oxidation processes; Periodate and Persulfate oxidations; Paraquat herbicide degradation; Response surface methodology; Central Composite Design (CCD), Kinetic study.

\section{Introduction}

Paraquat is a nonselective contact herbicide to control or suppress a broad spectrum of emerged weeds. It is the most toxic herbicide, the third most widely used herbicide in the world (Bromilow, 2004). The United States Environmental Protection Agency (USEPA), classified paraquat dichloride as a restricted use pesticide due to high acute toxicity to animals and people from intentional or inadvertent exposure with the acute oral toxicity of 4,4-bipyridyl with an $\mathrm{LD}_{50}$ value of $40-200 \mathrm{mg} / \mathrm{kg}$ body weight. It has life-threatening effects on the gastrointestinal tract, kidney, liver, heart and other organs (Agency U.S.E.P, 1997; Watts, 2011).

In recent years, AOPs intensively studied as the most environmental friendly and promising techniques for the degradation of recalcitrant organic pollutants in water by powerful oxidants especially hydroxyl radicals or superoxide radicals Barceló et al. 2004, Özkara, et al., 2016; Chu and Rao, 2012, Moro et al. 2013; Ameta, 2018; Kumar et al., 2017; Goel and Seepana, 2016; Miklos, 2018).

Heterogeneous photocatalytic degradation in presence of nanostructure catalysts attained good efficiencies in degradation of organic compounds among the various AOPs (Sillanpää and Matilainen, 2010; Znad et al, 2018). Heterogeneous photo-catalysis involves the use of a suspension of semiconductor powder (usually transition metal oxides) as a catalyst for AOPs. 
The process is photo-induced and requires irradiation for the activation of the catalyst (Hodges et al., 2018; Medynska, 2018; Moshe et al. 2009; Atalay and Ersöz, 2016). For example, metal-oxide nanoparticles of $\mathrm{TiO}_{2}$ have been extensively utilized in photocatalytic oxidation processes, due to high photocatalytic activity and nontoxic properties (Wang, 2016; Jain and Vaya, 2017; Razali et al., 2013; Sillanp, 2018). In the its photocatalytic activity process photo electrons in the conduction band and highly oxidative holes in the valence band are produced where a reaction occurs with the adsorbed water (i.e. surface hydroxyl) to form the highly reactive hydroxyl radicals according eq. 1 (Binas, 2017).

$$
\mathrm{TiO}_{2}+\mathrm{hr} \rightarrow \mathrm{e}^{-}+\mathrm{h}^{+}
$$

Thus, heterogeneous photo-catalysis technique considers particularly due to its ability to completely oxidize many organic compounds without the formation of hazardous by products (Zhu and Wang, 2017; Aramyan and Moussavi, 2017, Gupta, 2012) .

Inorganic oxidants such as $\mathrm{ClO}_{3}^{-}, \mathrm{BrO}_{3}^{-}, \mathrm{H}_{2} \mathrm{O}_{2}, \mathrm{~S}_{2} \mathrm{O}_{8}^{2-}$, and $\mathrm{IO}_{4}^{-}$used for removal and mineralization of various organic pollutants from aqueous solutions due to the synergistic effect in generated different highly reactive radicals in Hybridizing photo-oxidation process of various inorganic oxidants and be having better results in comparison to the individual processes Eskandarloo et al., 2015; Wang and Hong, 1999; Elddine, 2015; Jafarinejad, 2017, Ali and Hassan, 2008. They can activate by ultrasonic waves, heating, UV irradiation and also it can chemically activate using $\mathrm{Fe}^{0}, \mathrm{Fe}^{2+}, \mathrm{Zn}^{2+}$, etc Sharma et al., 2015; Sahoo, 2013.

Undergoing photolysis or thermolysis in aqueous solution, $\mathrm{S}_{2} \mathrm{O}_{8}^{2-}$ decomposes to generate the reactive radicals (eq. 2-4) (Cao, 2010; Chia et al, 2004).

$$
\mathrm{S}_{2} \mathrm{O}_{8}^{2-}+\mathrm{UV}(<270 \mathrm{~nm}) \rightarrow 2 \mathrm{SO}_{4}^{-}
$$




$$
\begin{aligned}
& 2 \mathrm{SO}_{4}^{-}+\mathrm{H}_{2} \mathrm{O} \rightarrow \mathrm{SO}_{4}^{2-}+\mathrm{HO}^{-}+\mathrm{H}^{+}(\text {at all pHs }) \\
& 2 \mathrm{SO}_{4}^{-}+\mathrm{OH}^{-} \rightarrow \mathrm{SO}_{4}^{2-}+\mathrm{HO}^{-}+\mathrm{H}^{+}(\text {at all pHs })
\end{aligned}
$$

Periodate as an inorganic oxidant can oxidize a wide range of organic compounds quickly due to generate highly reactive radicals and non-radical intermediates under photolysis in aqueous solution (eq.5-12) (Lia, 2016; Cantavenera, 2007)..

$$
\begin{aligned}
& \mathrm{IO}_{4}^{-}+\mathrm{hv} \rightarrow \mathrm{IO}_{3}^{-}+\mathrm{O}^{-} \\
& \mathrm{O}^{--}+\mathrm{H}^{+} \rightleftarrows \mathrm{OH}^{\cdot} \\
& \mathrm{OH}^{-}+\mathrm{IO}_{4}^{-} \rightarrow \mathrm{OH}^{-}+\mathrm{IO}_{4}^{-} \\
& 2 \mathrm{OH}^{\cdot} \rightarrow \mathrm{H}_{2} \mathrm{O}_{2} \\
& 2 \mathrm{IO}_{4}^{-} \rightleftarrows \mathrm{I}_{2} \mathrm{O}_{8} \\
& \mathrm{I}_{2} \mathrm{O}_{8}+\mathrm{H}_{2} \mathrm{O} \rightarrow \mathrm{IO}_{3}^{-}+\mathrm{IO}_{4}^{-}+2 \mathrm{H}^{+}+\mathrm{O}_{2} \\
& 2 \mathrm{IO}_{3} \rightleftarrows \mathrm{I}_{2} \mathrm{O}_{6} \\
& \mathrm{I}_{2} \mathrm{O}_{6}+\mathrm{H}_{2} \mathrm{O} \rightarrow \mathrm{IO}_{3}^{-}+\mathrm{IO}_{4}^{-}+2 \mathrm{H}^{+}
\end{aligned}
$$

The aim of this work is comparative study of the performance of UV/PS/TiO 2 and $\mathrm{UV} / \mathrm{PI} / \mathrm{TiO}_{2}$ as hybrid AOPs on removal of paraquat herbicide from aqueous solution. The process was modeled and optimized by response surface methodology (RSM). Also, kinetic and electrical cost estimation has been assessed.

\section{Experimental}

\subsection{Materials and instruments}

Standard solution of Paraquat (PQ, 42\%) with chemical name of 1,1dimethyl-4,4bipyridinium dichloride that its molecular structure is shown in supplementary Fig. 1, was prepared from Golsam chemicals Company. Anatase $\mathrm{TiO}_{2}$ Nano-powder (Purity: >99\%, 
APS: 10-25 nm, SSA: 200-240 $\mathrm{m}^{2} / \mathrm{g}$, Color: white) was purchased from US Research company as photo-catalysis that TEM and XRD analyses results are shown in supplementary Fig. 2 and 3. Sodium periodate (PI) and potassium persulfate (PS) were used as oxidant. Hydrochloric acid and sodium hydroxide were used to adjust solution $\mathrm{pH}$ and in all of the experiments deionized water was utilized to prepare solutions. All the chemicals were Merck and Fluka products.

Concentration of the PQ was measured by an UV-Vis spectrophotometer (Double beam Rally UV-2601). Total organic carbon (TOC) analysis was carried out by a multi N/C 3100 (Germany) instrument.

\subsection{Photochemical reactor}

An UVC lamp (Philips, $150 \mathrm{~W}$ and $\lambda_{\max }=254 \mathrm{~nm}$ ) was used as light source and fixed into quartz tube and located in the center of the reactor. A cylindrical pyrex container with volume of $500 \mathrm{~mL}$ which was equipped with a cooling jacket to control the temperature was used as reactor vessel. The reactor content was stirred by magnetic stirrer. The photo-reactor schematic is shows in Fig. 4. 


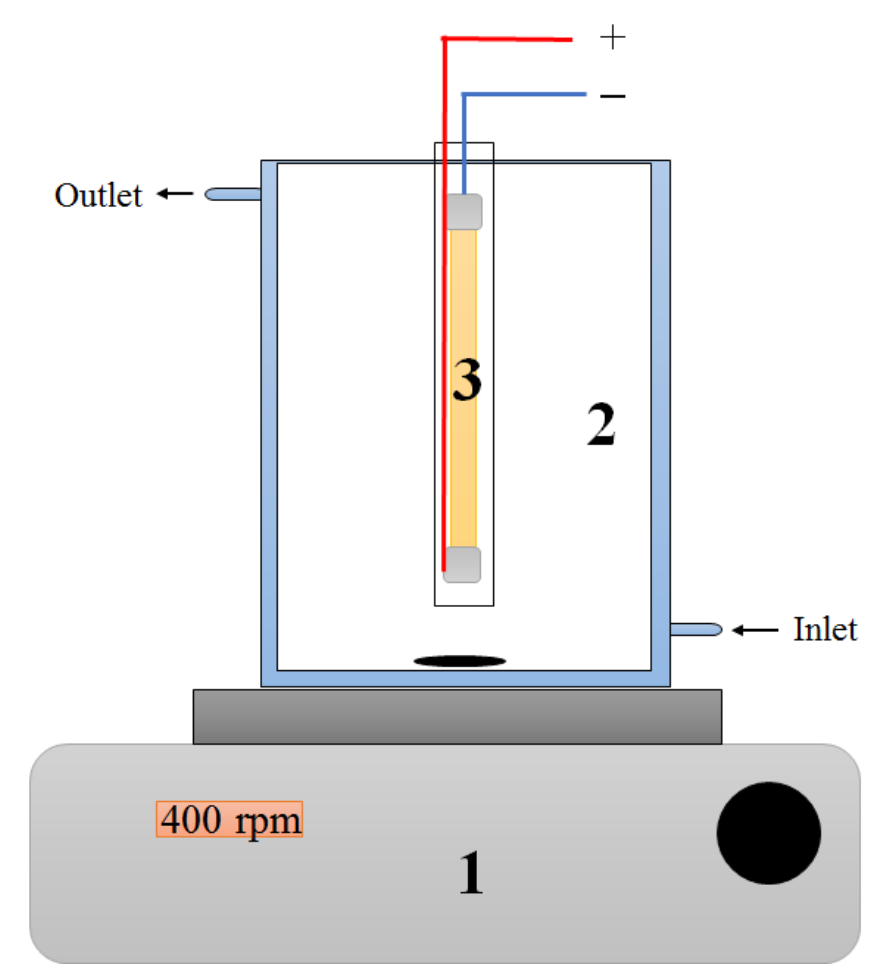

Fig 4. Schematic of the photo-reactor 1. Magnetic stirrer 2. Reactor vessel 3. UV lamp and its quartz cover

\subsection{Procedure}

In each run of the process, $400 \mathrm{~mL}$ of the PQ solution with desired initial concentration and $\mathrm{pH}$ value was transferred into the reactor. A certain amount of the $\mathrm{TiO}_{2}$ Nano-powder and inorganic oxidant were added, and after well mixing, the UV lamp was switched on to initiate the process. Samples at regular time intervals were withdrawn and degradation studies were carried out by measuring the absorbance at $\lambda_{\max }=258$ that corresponds to $\mathrm{C}=\mathrm{C}$ bands in pyridinium ring with the help of a UV-Vis spectrophotometer (Fig. 5) (Sahoo, 2012). Also, mineralization study was carried out by measuring the TOC of the samples (supplementary Fig. 6).

The percentages of degradation and mineralization are calculated according to the following equations: 
Degradation $\%=\frac{\mathrm{C}_{0}-\mathrm{C}_{\mathrm{i}}}{\mathrm{C}_{0}} \times 100 \%$

Where, $\mathrm{C}_{0}$ and $\mathrm{C}_{\mathrm{i}}$ are the concentration of the PQ before and after treatment.

$$
\text { Mineralization } \%=\frac{\mathrm{TOC}_{\text {initial }}-\mathrm{TOC}_{\mathrm{t}}}{\mathrm{TOC}_{\text {initial }}} \times 100 \%
$$

Where, TOC $t$ is the TOC at time ' $t$ ' (Sahoo, 2012).

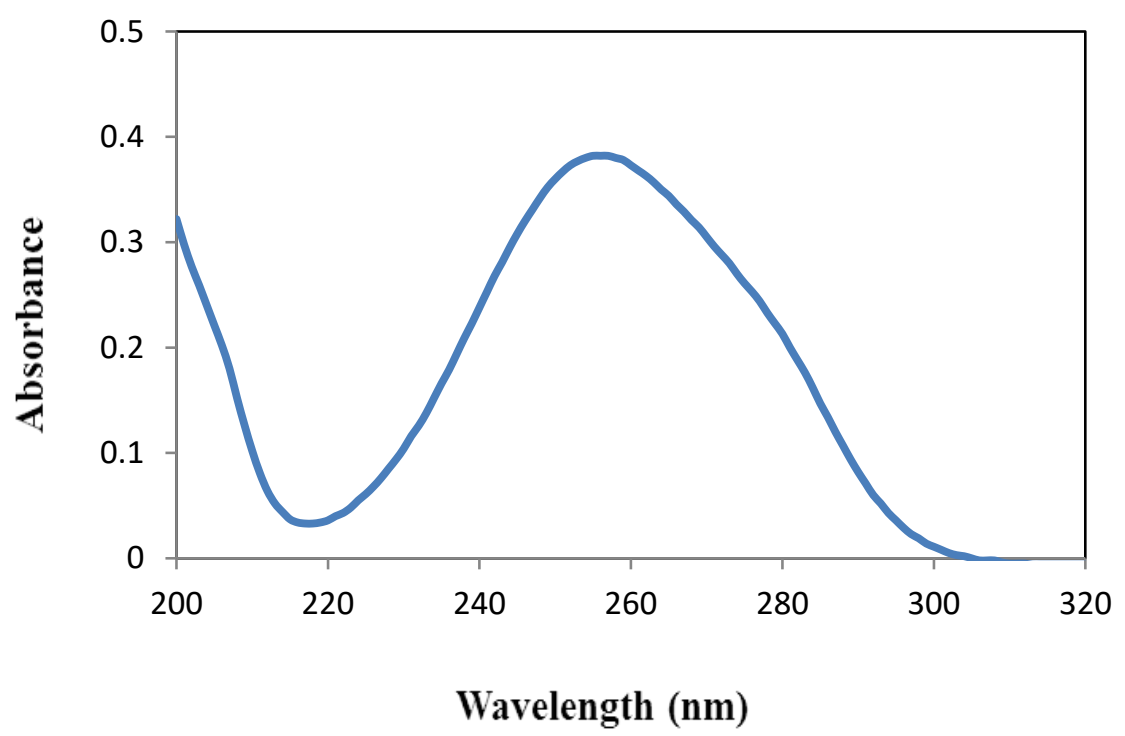

Fig. 5: UV spectrum of $[\mathrm{PQ}]=3 \mathrm{ppm}$

\subsection{Design of the experiments}

The effect of various experimental parameters on the processes degradation efficiency and their optimum values were studied using Central Composite Design (CCD) as one of important tools of Response Surface Methodology (RSM) (Montgomery, 2009). RSM is one useful mathematical and statistical method for analyzing the relation between several independent variables ( Beher et al., 2018). 
CCD is used to optimize the values of significant variables and obtaining the best quantitative response. Also, it reduces the effect of uncontrolled variables by the experiments are randomly examined (Vahidian et al.,2016).

The total number of experiments (N) can be determined as follow (Martins, 2017): (Raissi and Farsani, 2009)

$$
\mathrm{N}=2^{\mathrm{k}}+2 \mathrm{k}+\mathrm{N}_{0}
$$

where $k, 2^{k}, 2 k$ and $N_{0}$ are the number of factors, the terms of cubic points, axial points, and center points, respectively.

So, CCD is able to model and optimize related operational factors of the AOPs and can specify the possible interaction between them (Martins, 2017).

In this study, the three important factors, i.e. initial $\mathrm{pH}, \mathrm{TiO}_{2}$ nanoparticle dosage, and inorganic oxidant concentration were optimized based on obtained degradation efficiency (DE) of the PQ as the response via the CCD method.

\section{Results and discussion}

\subsection{Experimental design}

In order to design of the experiments, the effective operational parameters such as persulfate and periodate concentration, initial $\mathrm{pH}$, and $\mathrm{TiO}_{2}$ dosage have been considered to optimize by DOE software. Next, by introducing the parameters and their levels to the DOE software, 20 tests were designed to be done for both processes. The tests were performed and their correlated DE was calculated and introduced to the software as a response. The range of variables companion with designed experiments for $\mathrm{UV} / \mathrm{PS} / \mathrm{TiO}_{2}$ and $\mathrm{UV} / \mathrm{PI} / \mathrm{TiO}_{2}$ processes have been shown in table 1 and 2 respectively. 
Table 1: The range of variables and the designed experiments as well as corresponding responses for PS process ( $[\mathrm{PQ}]=30 \mathrm{mgL}^{-1}, \mathrm{~T}=25^{0} \mathrm{C}$ )

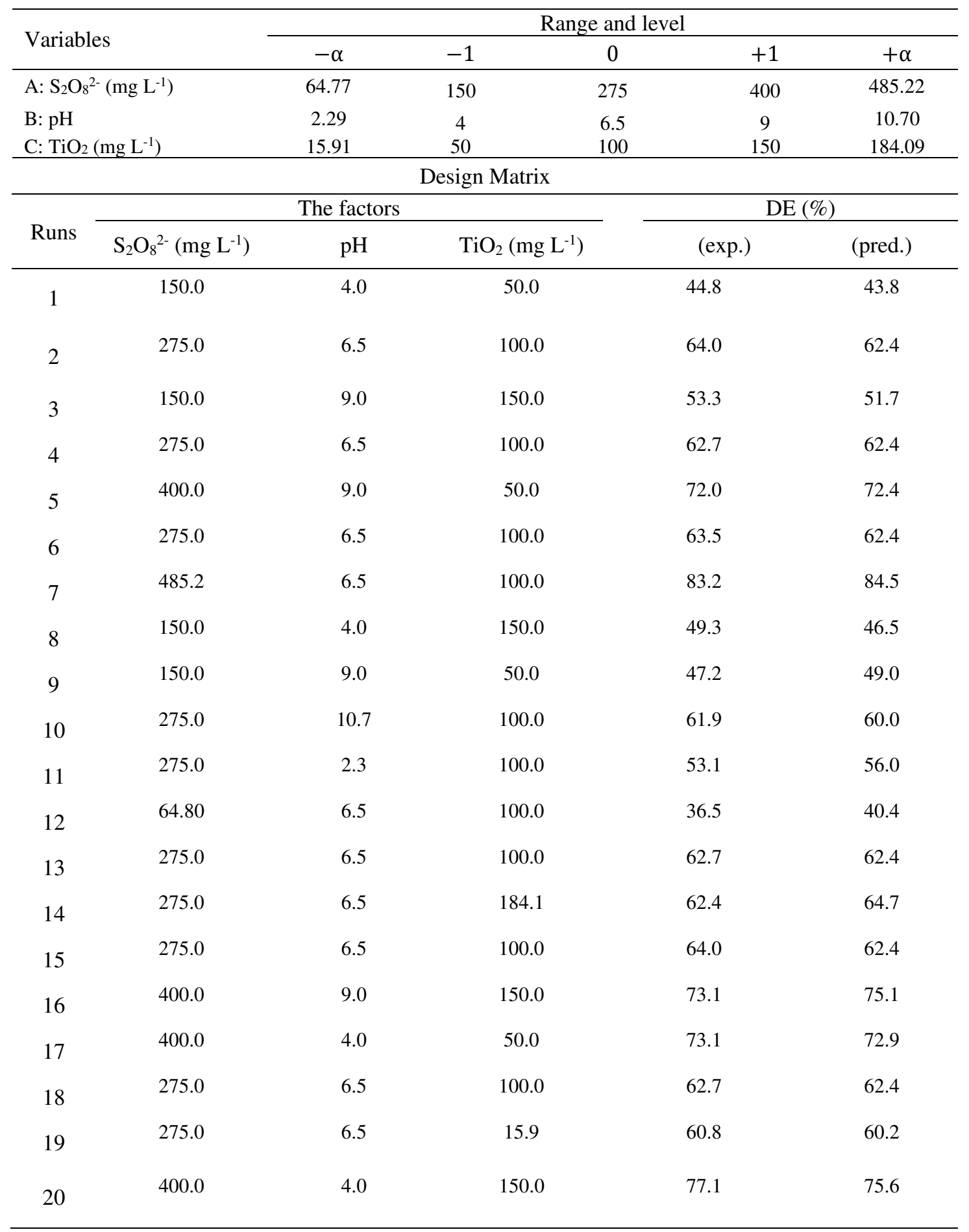


Table 2: The range of variables and the designed experiments as well as corresponding responses for PI process $\left([\mathrm{PQ}]=30 \mathrm{mgL}^{-1}, \mathrm{~T}=25^{0} \mathrm{C}\right)$

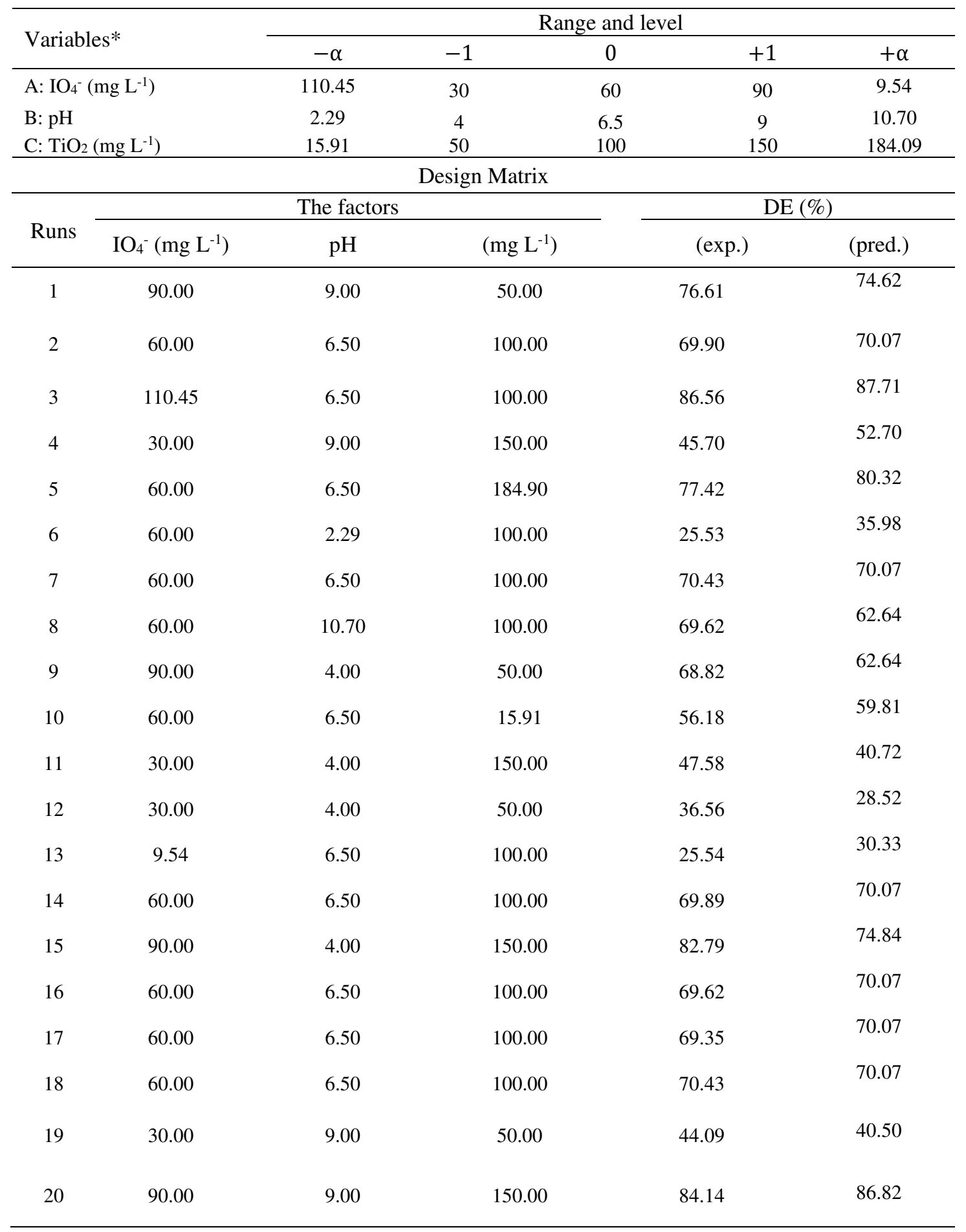


After regression analysis of the data, a second order polynomial equation was suggested by software to predict the response of the processes of UV/PS/ $\mathrm{TiO}_{2}$ and $\mathrm{UV} / \mathrm{PI} / \mathrm{TiO}_{2}$.

The significance of the model and its terms was evaluated by analysis of variance (ANOVA) such that p-values less than 0.05 and greater than 0.10 indicate the model terms are significant and not significant, respectively. The terms of $\mathrm{TiO}_{2} \mathrm{NPs}, \mathrm{pH}^{2}, \mathrm{PS}, \mathrm{PS} \times \mathrm{pH}$ in $P S$ process, and the terms of $\mathrm{PI}^{2}, \mathrm{pH}^{2}, \mathrm{TiO}_{2} \mathrm{NPs}$ in PI process, were significant. The ANOVA output for the reduced quadratic models (eq. 16 and 17) is demonestrated in table 3 and 4 for $\mathrm{UV} / \mathrm{PS} / \mathrm{TiO}_{2}$ and UV/PI/TiO 2 processes, respectively. The Model F-value of 110.37 and the p-value $<0.0001$ for $\mathrm{UV} / \mathrm{PS} / \mathrm{TiO}_{2}$ process and $\mathrm{F}$-value of 41.12 and the p-value $<0.0001$ for $\mathrm{UV} / \mathrm{PI} / \mathrm{TiO}_{2}$ process imply that the models are significant.

$\% \mathrm{DE}=9.01321+0.13468 \mathrm{PS}+4.99923 \mathrm{pH}+0.02698 \mathrm{TiO}_{2} \mathrm{NPs}-0.00459 \mathrm{PS} \times \mathrm{pH}-$ $0.25118 \mathrm{pH}^{2}$

$\% \mathrm{DE}=-64.83410+1.08949 \mathrm{PI}+20.05376 \mathrm{pH}+0.12196 \mathrm{TiO}_{2} \mathrm{NPs}-0.00434 \mathrm{PI}^{2}-$ $1.35832 \mathrm{pH}^{2}$

Table 3. Analysis of variance for the response surface reduced quadratic model for PS process

\begin{tabular}{cccccc}
\hline Source & $\begin{array}{c}\text { Sum of } \\
\text { Squares }\end{array}$ & df & $\begin{array}{c}\text { Mean } \\
\text { Square }\end{array}$ & F-Value & $\begin{array}{c}\text { p-value } \\
\text { Prob }>\text { F }\end{array}$ \\
\hline Model & 2443.11 & 5 & 488.62 & 110.37 & $<0.0001$ \\
$\mathrm{~A}-\mathrm{S}_{2} \mathrm{O}_{8}{ }^{2-}$ & 2346.59 & 1 & 2346.59 & 530.06 & $<0.0001$ \\
$\mathrm{~B}-\mathrm{pH}$ & 19.06 & 1 & 19.06 & 4.30 & 0.0569 \\
$\mathrm{C}-\mathrm{TiO}_{2}$ & 24.86 & 1 & 24.86 & 5.61 & 0.0327 \\
$\mathrm{AB}$ & 16.44 & 1 & 16.44 & 3.71 & 0.0746 \\
$\mathrm{~B}^{2}$ & 36.17 & 1 & 36.17 & 8.17 & 0.0126 \\
Residual & 61.98 & 14 & 4.43 & &
\end{tabular}




\begin{tabular}{lccccc} 
Lack of Fit & 59.79 & 9 & 6.64 & 15.15 & 0.0040 \\
Pure Error & 2.19 & 5 & & & \\
Cor Total & 2505.09 & 19 & 0.44 & \\
\hline
\end{tabular}

Table 4. Analysis of variance for the response surface reduced quadratic model for PI process

\begin{tabular}{cccccc}
\multicolumn{6}{c}{ quadratic model for PI process } \\
\hline Source & $\begin{array}{c}\text { Sum of } \\
\text { Squares }\end{array}$ & df & $\begin{array}{c}\text { Mean } \\
\text { Square }\end{array}$ & F-Value & $\begin{array}{c}\text { p-value } \\
\text { Prob }>\text { F }\end{array}$ \\
\hline Model & 6168.64 & 5 & 1233.73 & 41.12 & $<0.0001$ \\
${\mathrm{~A}-\mathrm{IO}_{4}{ }^{-}}$ & 3977.48 & 1 & 3977.48 & 132.57 & $<0.0001$ \\
$\mathrm{~B}^{\mathrm{p} H}$ & 489.86 & 1 & 489.86 & 16.33 & 0.0012 \\
$\mathrm{C}^{-T i O}{ }_{2}$ & 507.83 & 1 & 507.83 & 16.93 & 0.0011 \\
$\mathrm{~A}^{2}$ & 221.91 & 1 & 221.91 & 7.40 & 0.0166 \\
$\mathrm{~B}^{2}$ & 1048.98 & 1 & 1048.98 & 34.96 & $<0.0001$ \\
Residual & 420.03 & 14 & 30.00 & & \\
Lack of Fit & 418.49 & 9 & 46.50 & 150.81 & $<0.0001$ \\
Pure Error & 1.54 & 5 & 0.31 & & \\
Cor Total & 6588.67 & 19 & & & \\
\hline
\end{tabular}

The "Pred R-Squared" of 0.93 and "Adj R-Squared" of 0.97 represent that the model predicts the response as well, and the "Adeq Precision" of 38.26 indicates an adequate signal to noise (a ratio greater than 4 is desirable). The $\mathrm{R}^{2}$ of 0.97 implies that the model can predict the $\mathrm{UV} / \mathrm{PS} / \mathrm{TiO}_{2}$ process performance. Also, in the case of $\mathrm{UV} / \mathrm{PI} / \mathrm{TiO}_{2}$ process, the "Pred $\mathrm{R}$ Squared" and "Adj R-Squared", and “Adeq Precision" were 0.78, 0.91, and 19.73 respectively. The $\mathrm{R}^{2}$ of 0.94 implies that the model can predict the UV/PI/TiO 2 process performance. The adequacy of the models was graphically evaluated and approved by diagnostic plots (supplementary Fig. 7a-b).

\subsection{Effect of operational parameters and process optimization}

The effect of operating factors on the process was assessed by three dimensional surface graphs. Figs. 8 and 9 show variation of the the degradation efficiency as a function of the initial $\mathrm{pH}$ and dose of $\mathrm{TiO}_{2} \mathrm{NPs}$ and oxidant dosage (PS and PI), while the PQ initial 
concentration is $30 \mathrm{mgL}^{-1}$ at all tests. Fig. 8 shows the PI process efficiency at neutral condition is more than the alkaline and acidic conditions and it decreases at acidic conditions intensitly, while activity of PS independent from $\mathrm{pH}$ variations approximately. Fig. 9 shows the degradation efficiency is increased by increasing the PI, PS and $\mathrm{TiO}_{2} \mathrm{NPs}$ concentrations for both processes, in constant $\mathrm{pH}$. This increasing is very intensive for PI due to production of more radicals (eqs. 5-12). So, it is a stronger and more active oxidizer.
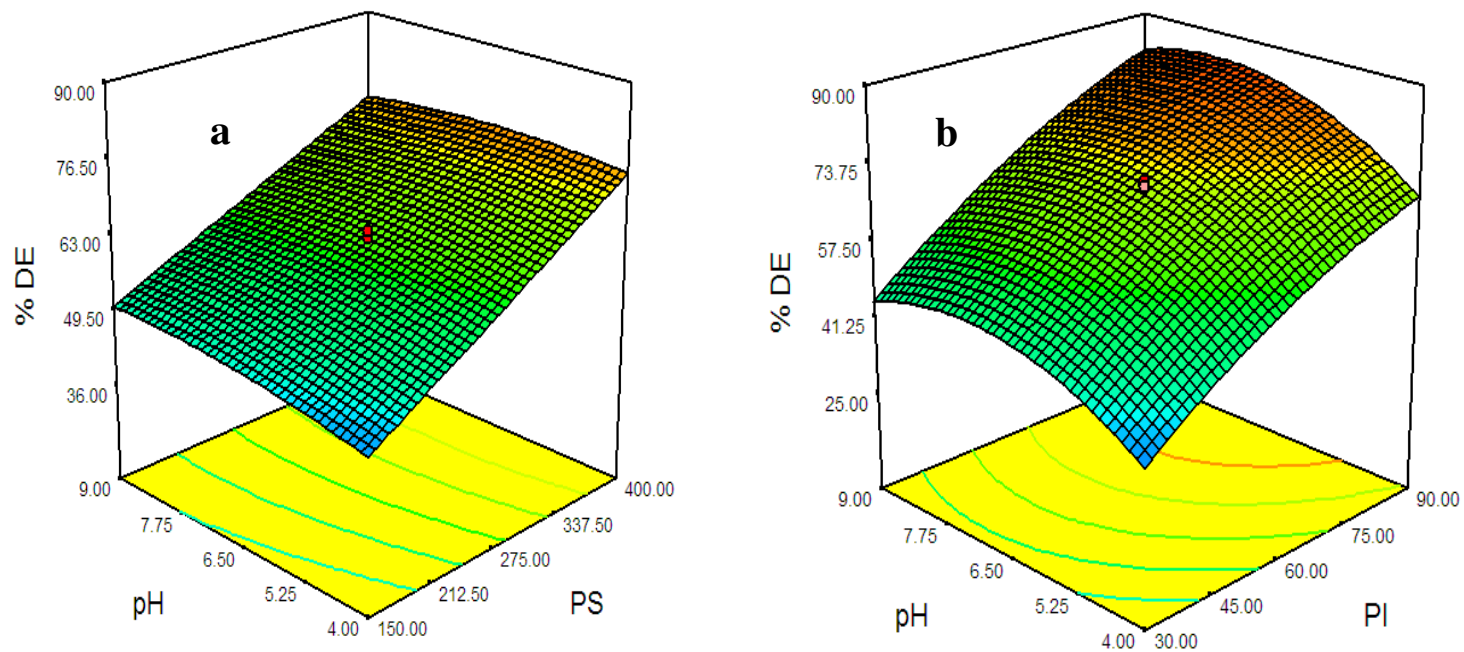

Fig. 8: Response surface graphs of the variation of the DE versus: (a) the initial pH and the PS amount $\left(\mathrm{mgL}^{-1}\right),(\mathrm{b})$ initial $\mathrm{pH}$ and $\mathrm{PI}$ amount $\left(\mathrm{mgL}^{-1}\right)\left([\mathrm{PQ}]=30 \mathrm{mgL}^{-1}\right.$ and $\left.\mathrm{T}=25^{\circ} \mathrm{C}\right)$ 

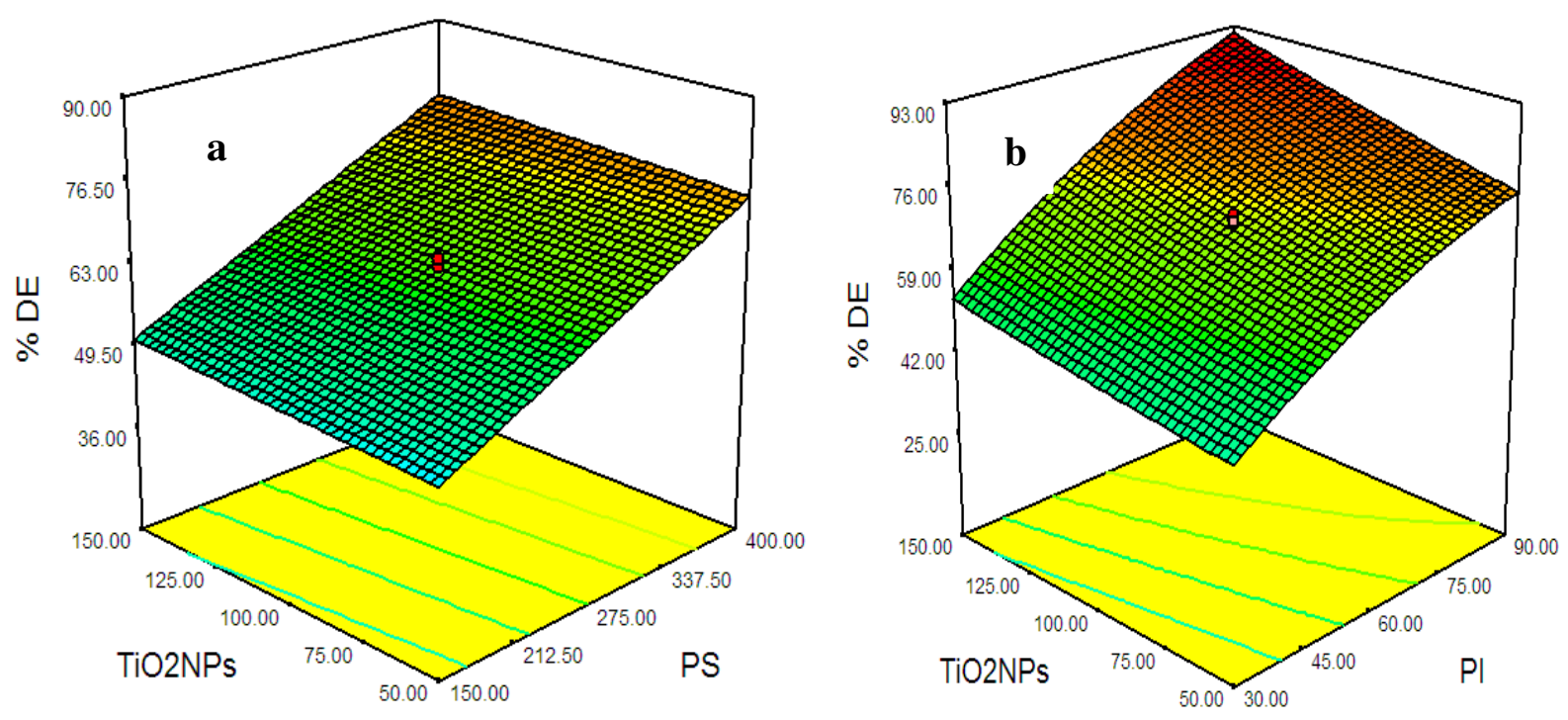

Fig. 9: Response surface graph of the variation of the DE versus: (a) the initial pH and the PS amount, (b) initial $\mathrm{pH}$ and $\mathrm{PI}$ amount $\left([\mathrm{PQ}]=30 \mathrm{mgL}^{-1}\right.$ and $\left.\mathrm{T}=25^{\circ} \mathrm{C}\right)$

The operation parameters were optimized numrically based on the proposed reduced models (eqs. 16 and 17) using related numerical facilities of the applied software. To this aim, goals of the three variables and the model response were set at "in the range" and "maximizing" respectively. Desirability ramps for the numerical optimization of the $\mathrm{UV} / \mathrm{PS} / \mathrm{TiO}_{2}$ and $\mathrm{UV} / \mathrm{PI} / \mathrm{TiO}_{2}$ processes have been shown in supplementary Fig. 10 and 11. For PS process in the optimum condition of $[\mathrm{PS}]=400 \mathrm{mgL}^{-1},\left[\mathrm{TiO}_{2} \mathrm{NPs}\right]=150 \mathrm{mgL}^{-1}$ and $[\mathrm{pH}]_{\mathrm{in}}=6.3$ the predicted $\mathrm{DE}$ is about $77 \%$. Also, DE for PI process is about $87 \%$ in the optimum condition of $[\mathrm{PI}]=88 \mathrm{mgL}^{-1}$, $\left[\mathrm{TiO}_{2} \mathrm{NPs}\right]=125 \mathrm{mgL}^{-1}$ and $[\mathrm{pH}]_{\mathrm{in}}=7.5$. To assess accuracy of the model prediction, under the supposed values of the parameters, the photocatalytic degradation efficiency empirically reached to $90 \%$ (i.e. $3 \%$ error) for PI process and $83 \%$ (i.e. $6 \%$ error) for PS process.

\subsection{The process details and kinetic study}

The degradation kinetic of the PQ was tested separately under their optimum conditions for both processes. The linear relationship between the investigated results for both the PS 
and PI processes shows that they follow the first-order kinetics which the fitting is shown in Fig. 12. Plotting variation of the logarithmic concentration ratio versus the irradiation time forms a straight line with a slope equal to the $\mathrm{k}_{\mathrm{app}}$. Kinetic constant was $0.0299 \mathrm{~min}^{-1}$ for PS process and $0.0604 \mathrm{~min}^{-1}$ for PI process.
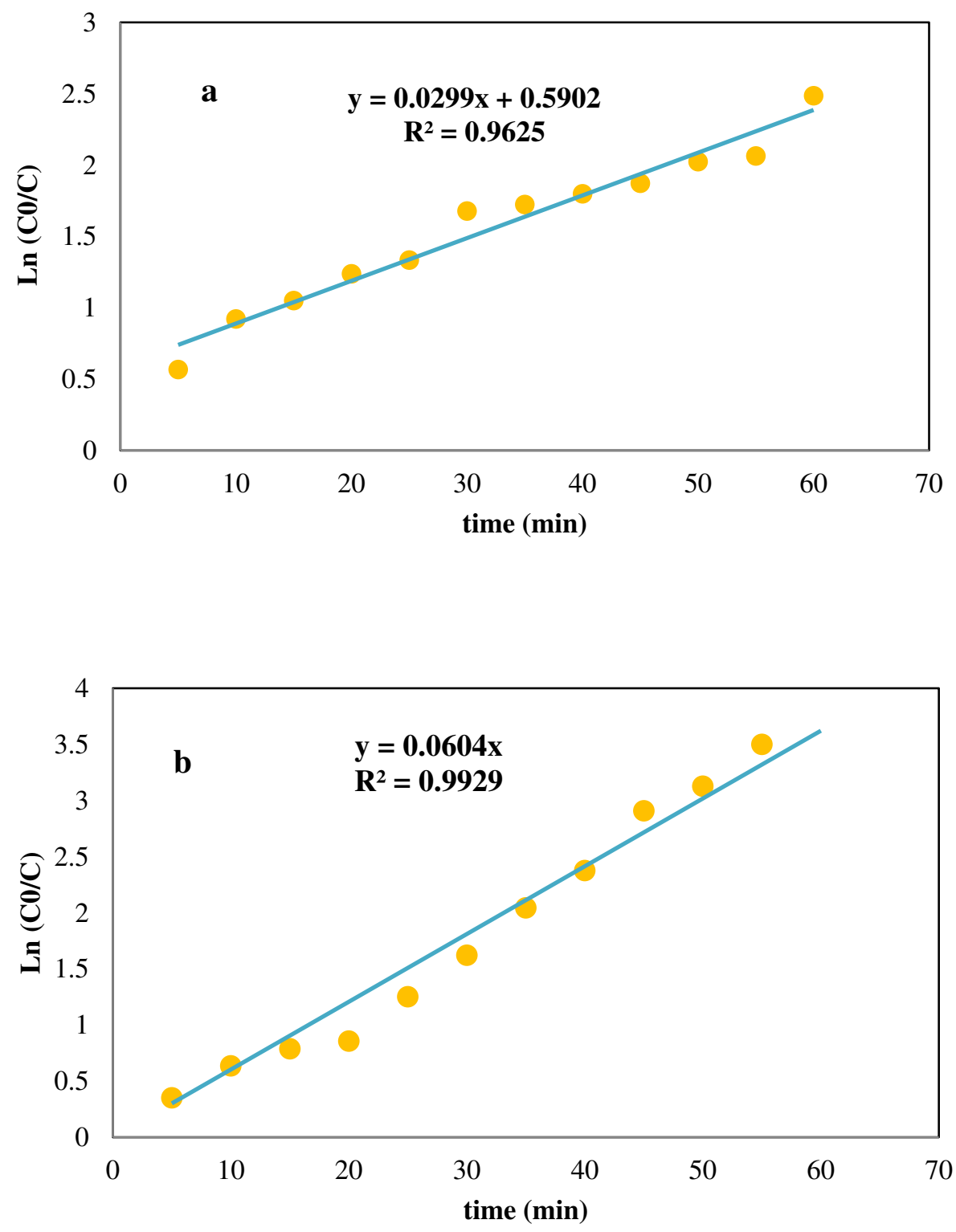

Fig. 12: linear fitting of first order kinetic model for the $P Q$ degradation $\left(P Q=30 \mathrm{mg} \mathrm{L}^{-1}\right.$ and $\left.T=25^{\circ} \mathrm{C}\right)$ a) PS and b) PI process 


\subsection{Mineralization}

Mineralization is a process of the complete oxidative degradation of organics and relevant intermediates to $\mathrm{CO}_{2}, \mathrm{H}_{2} \mathrm{O}$ and other mineral oxides (Saien, 2017; Marien, 2016). For detection of reduction in the PQ concentration, the UV-Vis spectrophotometry analysis is used, and to investigate the mineralization, total organic carbon (TOC) test should be used. This test was performed on the treated PQ solution by the photocatalytic process under the found optimum conditions. The TOC results showed that the photocatalytic process of UV/PS/TiO 2 and $\mathrm{UV} / \mathrm{PI} / \mathrm{TiO}_{2}$ are able to mineralize the PQ solution about $32 \%$ and $55 \%$ respectively after 40 $\min$.

\subsection{Electrical energy consumption}

The electrical energy consumption (EEC) is one of the important criteria in the photochemical process. The figure-of-merit is the electrical energy per order, defined as the number of KWh of electrical energy required for reducing the concentration of a pollutant by 1 order of magnitude (i.e. $90 \%$ degradation), in $1 \mathrm{~m}^{3}$ of contaminated water, and can be calculated as (Bolton, 2001):

$\mathrm{EEC}=\frac{1000 \mathrm{pt}}{60 \mathrm{Vlog}\left(\frac{\mathrm{PQ}]_{0}}{[\mathrm{PQ}]}\right)}$

where $\mathrm{P}$ is the electrical power $(\mathrm{kW})$ of the light source in the photochemical system, $\mathrm{V}$ is the volume (L) of the treated solution, and $t$ is the time of irradiation (min). According to the first-order kinetic for the photocatalytic process, the constant ratio of log $\left([\mathrm{PQ}]_{0} /[\mathrm{PQ}]\right) / \mathrm{t}$ represents the rate constant, $\mathrm{k}$ (in unit of $\mathrm{min}^{-1}$ ), and therefore, eq. 18 can be rewritten as:

$$
\mathrm{EEC}=\frac{38.4 \times \mathrm{P}}{\mathrm{V} \times \mathrm{k}}
$$


Hence, under the optimum conditions of the photocatalytic PS and PI processes and considering to the rate constant of $0.0299 \mathrm{~min}^{-1}$ for PS process and $0.0604 \mathrm{~min}^{-1}$ for PI process, $150 \mathrm{~W}$ light source and 0.4 liter of treated PQ solution, the EEC is calculated as $481.60 \mathrm{kWh} / \mathrm{m}^{3}$ for PS process and $238.41 \mathrm{kWh} / \mathrm{m}^{3}$ for PI process after $60 \mathrm{~min}$.

\section{Conclusion}

In this study a photocatalytic process using $\mathrm{TiO}_{2}$ nanoparticles $\left(\mathrm{TiO}_{2} \mathrm{NPs}\right)$, persulfate (PS) and periodate (PI) oxidizers was applied to degrade of the paraquat (PQ) molecules as a high toxic herbicide. The experiments were designed based on CCD method and also, the processes were modeled. Concisely, the following outstanding information can be briefly stated from this study:

A reduced second order equation could model the photocatalytic degradation efficiency as a function of the initial $\mathrm{pH}$, the $\mathrm{PQ}$, $\mathrm{PS}$, and $\mathrm{PI}$ concentration, and the $\mathrm{TiO}_{2} \mathrm{NPs}$ dosage.

$>$ The operating parameters were optimized based on the models as: the initial $\mathrm{pH}=6.3$, $[\mathrm{PS}]=400 \mathrm{mg} / \mathrm{L}$, and $\left[\mathrm{TiO}_{2} \mathrm{NPs}\right]=150 \mathrm{mg} / \mathrm{L}$ for PS process and the initial $\mathrm{pH}=7.5$, $[\mathrm{PI}]=88 \mathrm{mg} / \mathrm{L}$, and $\left[\mathrm{TiO}_{2} \mathrm{NPs}\right]=125 \mathrm{mg} / \mathrm{L}$ for PI process were obtained. Under the conditions, the models predicted efficiency about $77 \%$ for UV/PS/ $\mathrm{TiO}_{2}$ and $87 \%$ for $\mathrm{UV} / \mathrm{PI} / \mathrm{TiO}_{2}$ which they were confirmed empirically with only 6 and $3 \%$ error.

$>$ The photocatalytic PQ degradation for both processes was well fitted by a pseudo first order kinetic model with rate constant of $0.0299 \mathrm{~min}^{-1}$ for UV/PS/TiO 2 process and $0.0604 \mathrm{~min}^{-1}$ for $\mathrm{UV} / \mathrm{PI} / \mathrm{TiO}_{2}$ process.

Under the optimum conditions, the PQ molecules were mineralized about 47.5 and $57 \%$ after $80 \mathrm{~min}$ for $\mathrm{UV} / \mathrm{PS} / \mathrm{TiO}_{2}$ and $\mathrm{UV} / \mathrm{PI} / \mathrm{TiO}_{2}$ processes, respectively. 
$>$ The electrical energy consumption for the photocatalytic process performance at the optimum condition after $60 \mathrm{~min}$ were calculated as $481.60 \mathrm{kWh} / \mathrm{m}^{3}$ for $\mathrm{UV} / \mathrm{PS} / \mathrm{TiO}_{2}$ process and $238.41 \mathrm{kWh} / \mathrm{m}^{3}$ for $\mathrm{UV} / \mathrm{PI} / \mathrm{TiO}_{2}$ process.

Based on the obtained results, periodate is a stronger, more active, and economical oxidizer than persulfate.

Ethical Approval and Consent to Participate: Not applicable

Consent to Publish: Not applicable

Author's contributions: Dr. Ghadamali Bagherian: supervision and finalization of the manuscript, Dr. Hadi rezaei vahidian: advisor and design of experiments, Mis Azam ghavi: doing the experiment and writing the original draft of the manuscript. It is confirmed that the manuscript has been read and approved by all named authors and is confirmed that the order of authors listed in the manuscript has been approved by all of authors.

Funding: There is no significant financial support for this work that could have influenced its outcome.

Competing interest: The authors declare that there is no conflict of interest associated with this publication.

Data availability: The datasets used and/or analyzed during the current study are available from the corresponding author on reasonable request.

\section{References:}

Agency, U.S.E.P., (1997), Paraquat Dichloride, in Reregistration Eligibility Decision(RED). Washington, D.C. 20460. 
Ali R, Hassan SH (2008) Degradation studies on paraquat and malathion using $\mathrm{TiO}_{2} / \mathrm{ZnO}$ based photocatalyst. Malaysian J Anal Sci 12: 77-87.

Ameta SC(2018) Introduction in Advanced Oxidation Processes for Waste Water Treatment. Emerging Green Chemical Technology: PAHER University, Udaipur, Rajasthan, India,. 1-12.

Aramyan SM, Moussavi M, 2017, Advances in Fenton and Fenton Based Oxidation Processes for Industrial Effluent Contaminants Control-A Review, Int. J. Environ. Sci. Nat. Resour. 2, 115-132. https://doi. 10.19080/IJESNR.2017.02.555594.

Atalay S, Ersöz G(2016) Review on Catalysis in Advanced Oxidation Processes in Springer Briefs in Molecular Science. Novel Catalysts in Advanced Oxidation of Organic Pollutants 35-58.

Beher SK(2018) Application of response surface methodology (RSM) for optimization of leaching parameters for ash reduction from low-grade coal. Int J Mining Sci Technol 28:621-629. http:// doi:10.1016/J.IJMST.2018.04.014.

Binas $\mathrm{V}(2017)$ Modified $\mathrm{TiO}_{2}$ based photocatalysts for improved air and health quality. J. Materiomics 1, 3-16. https://doi.org/10.1016/j.jmat.2016.11.002.

Bolton JR, (2001) Figures-of-merit for the technical development and application of advanced oxidation technologies for both electric-and solar-driven systems (IUPAC Technical Report), Pure Appl Chem 73: 627-637. http://doi: 10.1351/pac200173040627

Bromilow R H (2004) Paraquat and sustainable agriculture, Pest manag. sci. 60, 340-349. http// doi: $10.1002 / p s .823$.

Cantavenera M J(2007) Photocatalytic degradation of paraquat and genotoxicity of its intermediate products. J Photochem Photobiol A: Chemistry 185:277-282. https://doi.org/10.1016/j.jphotochem.2006.06.021.

Cao MH(2010) Photochemical decomposition of perfluorooctanoic acid in aqueous periodate with VUV and UV light irradiation. J Hazard Mater 179:1143-1146. https://doi.org/10.1016/j.jhazmat.2010.02.030.

Chia LH, Tang X, Weavers LK(2004) Kinetics and mechanism of photoactivated periodate reaction withChlorophenol in acidic solution. Environ Sci Technol 38.

Chu W, Rao YF (2012) Photocatalytic oxidation of monuron in the suspension of $\mathrm{WO}_{3}$ under the irradiation of UV-visible light. Chemosphere 86: 1079-1086. https://doi.org/10.1016/j.chemosphere.2011.11.062.

Del Moro G, Mancini A, Mascolo G, Di Iaconi C (2013), Comparison of UV/ $\mathrm{H}_{2} \mathrm{O}_{2}$ based AOP as an end treatment or integrated with biological degradation for treating landfill leachates. Chem Eng $\mathrm{J}$ 218: 133-137. https://doi.org/10.1016/j.cej.2012.12.086.

Elddine HAN (2015) Kinetic study of the discoloration of the food colorant E131 by $\mathrm{K}_{2} \mathrm{~S}_{2} \mathrm{O}_{8}$ and $\mathrm{KIO}_{3}$. Port Electrochim Acta 5:275-288 http://dx.doi.org/10.4152/pea.201505275 .

Eskandarloo H, Badiei A., Behnajady MA, (2015) Optimization of UV/inorganic oxidants system efficiency for photooxidative removal of an azo textile dye. Desalin Water Treat 1: 210-226. https://doi.org/10.1080/19443994.2014.912965.

Goel M, Seepana M (2016) Photochemical removal of pesticides: A Review. Mater Sci Forum 855: 127-138. http://doi: 10.4028/www.scientific.net/MSF.855.127.

Gupta VK (2012) Chemical treatment technologies for waste-water recycling-an overview. RSC Adv 2: 6380-6388. https://doi: 10.1039/C2RA20340E.

Hodges B C, Cates EL, Kim JH (2018) Challenges and prospects of advanced oxidation water treatment processes using catalytic nanomaterials. Nat Nanotechnol1: 642-650. http:// doi: 10.1038/s41565-018-0216-x. 
Jafarinejad S (2017) Cost-Effective catalytic materials for AOP treatment units in applications of advanced oxidation processes (AOPs) in drinking water treatment. Springer International Publishing AG: The Handbook of Environmental Chemistry, 309-343.

Jain A, Vaya D(2017) Photocatalytic Activity of $\mathrm{TiO}_{2}$ Nanomaterial. J Chil Chem Soc 62: 3683-3690 http://dx.doi.org/10.4067/s0717-97072017000403683.

Kumar MS, Sonawane SH, Pandit AB (2017) Degradation of methylene blue dye in aqueous solution using hydrodynamic Cavitation based hybrid advanced oxidation processes. Chem Eng Process 122: 288-295. https://doi.org/10.1016/j.cep.2017.09.009.

LiaT(2016) Transformation of humic acid and halogenated byproduct formation in UV-chlorine processes. Water Res 102: 421-427. https://doi.org/10.1021/es049155n.

Miklos DB (2018) Evaluation of advanced oxidation processes for water and wastewater treatment A critical review. Water Res 139:118-131. https://doi.org/10.1016/j.watres.2018.03.042

Martins LR(2017) Optimization of cellulose and sugarcane bagasse oxidation: Application for adsorptive removal of crystal violet and auramine-O from aqueous solution. J Colloid Interf Sci 494: 223-241. https://doi.org/10.1016/j.jcis.2017.01.085.

Marien $\mathrm{CBD}(2016) \mathrm{TiO}_{2}$ Nanotube arrays: Influence of tube length on the hotocatalytic degradation of Paraquat. Appl Catal B Environ 194: 1-6. https://doi.org/10.1016/j.apcatb.2016.04.040.

Medynska A Z (2018) Photocatalysis in Metal Oxide-Based Photocatalysis: Fundamentals and Prospects for Application. G. korotcenkov (ed) 279-282.

Montgomery DC(2009) Design and Analysis of Experiments, 9ed, Arizona State University: Wiley.

MosheT B, Dror I, Berkowitz B (2009) Oxidation of organic pollutants in aqueous solutions by nanosized copper oxide catalysts. Appl Cata B Environ 85: 207-211. https://doi.org/10.1016/j.apcatb.2008.07.020.

Özkara A, Akyıl D, Konuk M., Pesticides, Environm. Pollut. Health, IntechOpen.

Rodriguez-Mozaz S, López J, Alda M, Barceló D, (2004) Monitoring of estrogens, pesticides and bisphenol A in natural waters and drinking water treatment plants by solid-phase extraction-liquid chromatography-mass spectrometry. J Chromato A 1045: 85-92

Raissi S, Farsani R E(2009) Statistical process optimization through multi-response surface methodology. World Acad Sci 51. https://zenodo.org/badge/DOI/10.5281/zenodo.1083451.svg.

Razali MH, Ruslimie CA, Khairul WM(2013) Modification and performances of $\mathrm{TiO}_{2}$ photocatalyst towards degradation of paraquat dichloride. J Sustain Sci Manag 8:244-253.

Sillanpää M, Matilainen A(2010) NOM Removal by Advanced Oxidation Processes in natural organic matter in water, Characterization and Treatment Methods. Chemosphere 80:159-211. http://doi: 10.1016/j.chemosphere.2010.04.067.

Sillanp M, Ncibi MCA(2018) Advanced oxidation processes for the removal of natural organic matter from drinking water sources: A comprehensive review. J Environ Manage 208:56-76. https://doi.org/10.1016/j.jenvman.2017.12.009.

Sahoo MK(2012) UVC induced TOC removal studies of Ponceau S in the presence of oxidants: Evaluation of electrical energy efficiency and assessment of biotoxicity of the treated solutions by Escherichia coli colony forming unit assay. Chem Eng J 213: 142-149. https://doi.org/10.1016/j.cej.2012.10.002.

Sahoo MK.(2013) Improving the operational parameters with high electrical energy efficiency for UVC induced advanced oxidation and mineralization of Acid blue 29: Generation of eco-friendly effluent. Sep Purif Technol 106: 110-116. https://doi.org/10.1016/j.seppur.2013.01.004. 
Saien J (2017) Photo-activated Periodate in homogeneous degradation and mineralization of quinoline: Optimization, Kinetic, and Energy Consumption. Environ Prog Sustain Energy 36: 1621-1627 https://doi.org/10.1002/ep.12615.

Sharma J, Mishra IM, Kumar V (2015) Degradation and mineralization of Bisphenol A (BPA) in aqueous solution using advanced oxidation processes: $\mathrm{UV} / \mathrm{H}_{2} \mathrm{O}_{2}$ and $\mathrm{UV} / \mathrm{S}_{2} \mathrm{O}_{8}{ }^{2-}$ oxidation systems, J. Environ. Manage. 156:266-275. http://dx.doi.org/doi:10.1016/j.jhazmat.2016.01.068 HAZMAT 17420.

Vahidian HR, Zarei AR, Soleymani AR(2016) .Degradation of nitro-aromatic explosives using recyclable magnetic photocatalyst: Catalyst synthesis and process optimization. J Hazard. Mater 325: 310-318. https://doi.org/10.1016/j.jhazmat.2016.12.001.

Wang Y, Hong CS (1999) Effect of hydrogen peroxide, periodate and persulfate on photocatalysis of 2-chlorobiphenyl in aqueous $\mathrm{TiO}_{2}$ suspensions. Water Res 9:2031-2036. https://doi.org/10.1016/S0043-1354(98)00436-9.

Watts M (2016) Paraquat, P.A.N.A.a.t. Pacifi (ed). Malaysia.

Wang Y(2016) The application of nano- $\mathrm{TiO}_{2}$ photo semiconductors in agriculture. Nanoscale Res Lett 11:1-7. http:// doi: 10.1186/s11671-016-1721-1.

Zhu S, Wang D (2017) Photocatalysis: Basic Principles, Diverse Forms of Implementations and Emerging Scientific Opportunities. Adv Energy Mat 7. http:// doi: 10.1002/aenm.201700841

Znad H, Abbas Kh, Hena S, Awual M R (20018) Synthesis a novel multilamellar mesoporous $\mathrm{TiO}_{2} / \mathrm{ZSM}-5$ for photo-catalytic degradation of methyl orange dye in aqueous media. $\mathrm{J}$ Env Chem Eng 6: 218-227. https://doi.org/10.1016/j.jece.2017.11.077. 
Figures

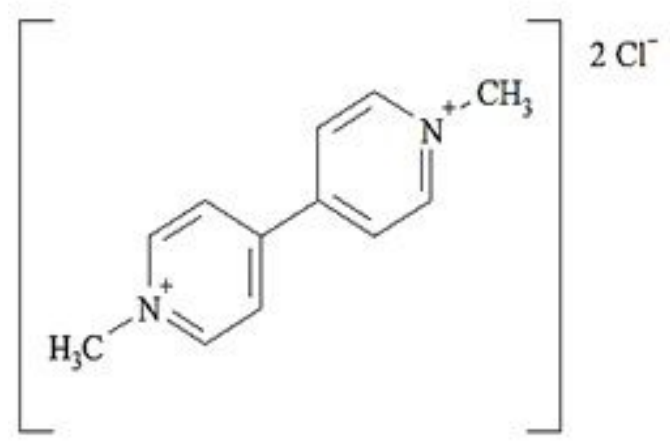

Figure 1

Molecular structure of PQ (Watts 2011)

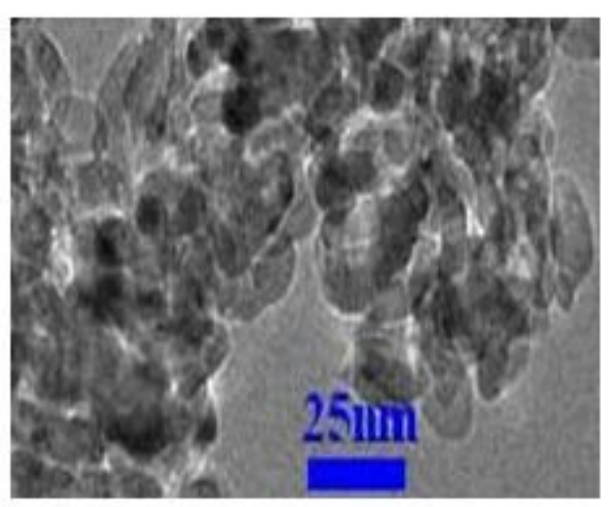

Figure 2

TEM image of the TiO2 nanoparticles 

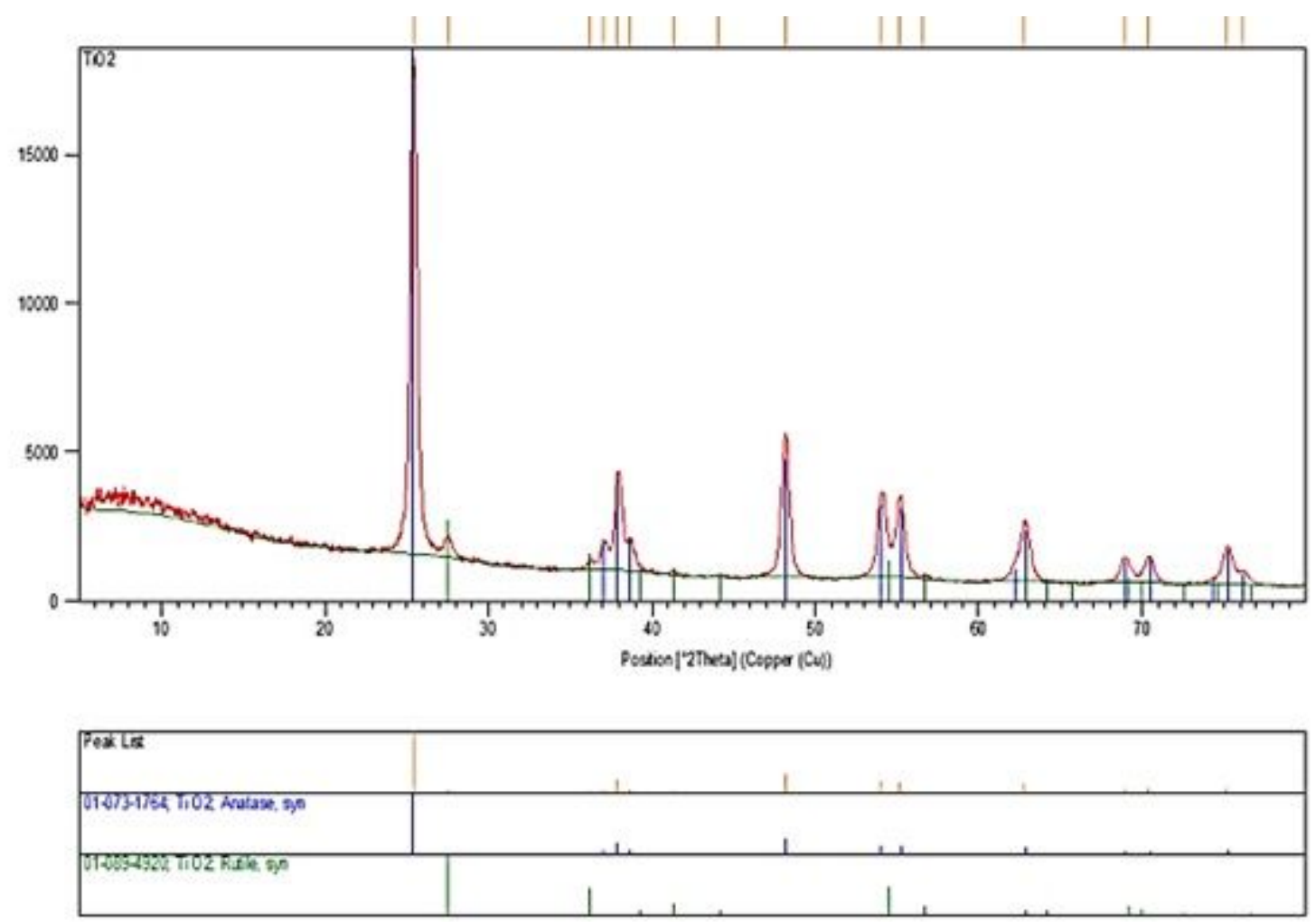

Figure 3

XRD pattern of the nanoparticles anatase TiO2

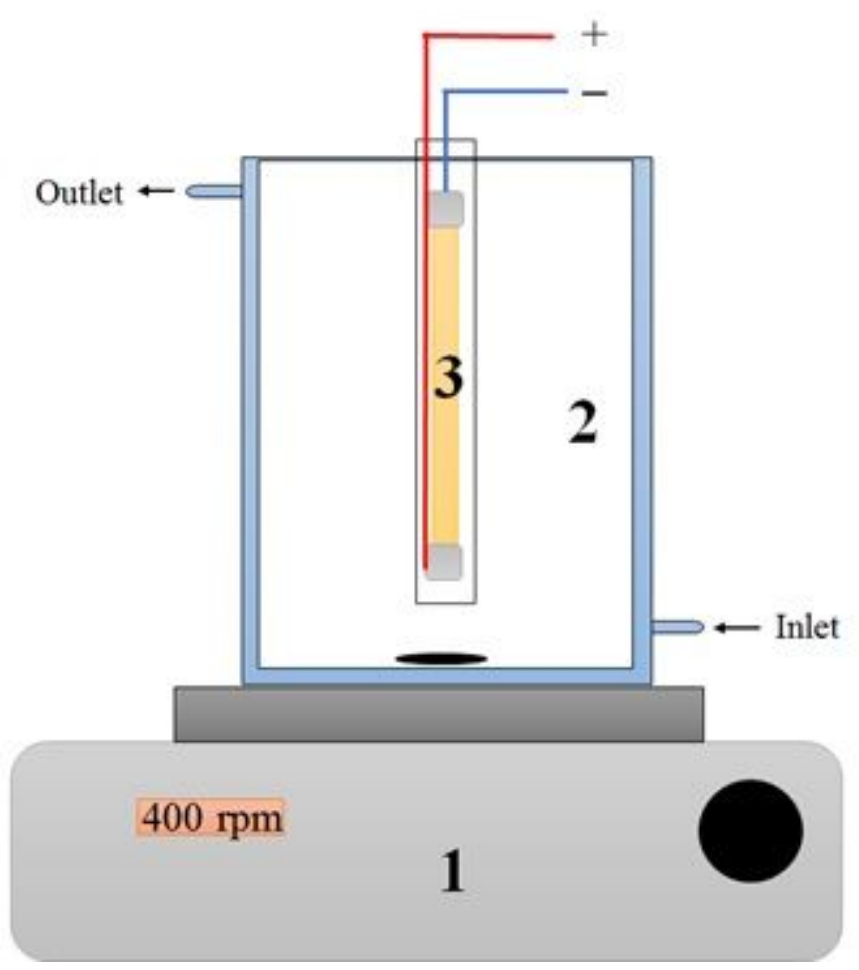

Figure 4

Schematic of the photo-reactor 1. Magnetic stirrer 2. Reactor vessel 3. UV lamp and its quartz cover 


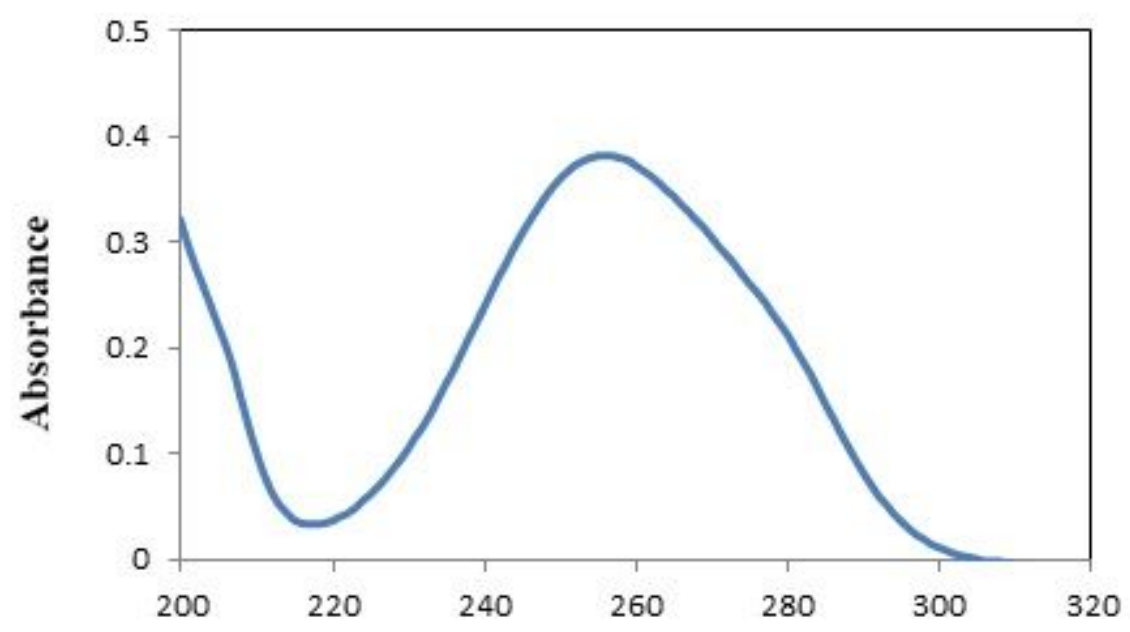

Wavelength $(\mathrm{nm})$

Figure 5

UV spectrum of $[\mathrm{PQ}]=3 \mathrm{ppm}$

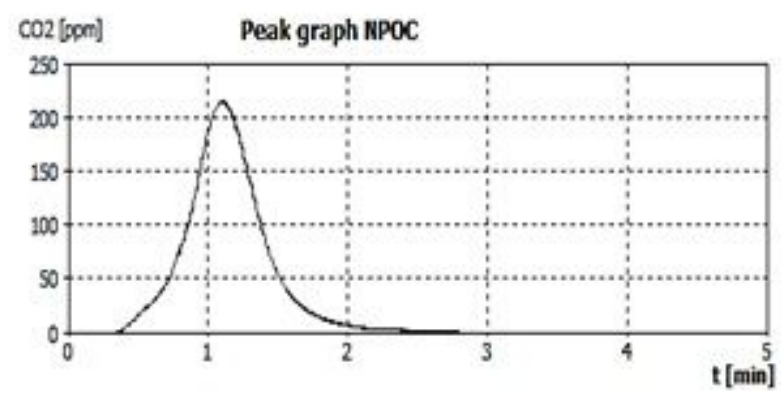

Figure 6

TOC graph of $[P Q]=30 \mathrm{mgL}-1$ 

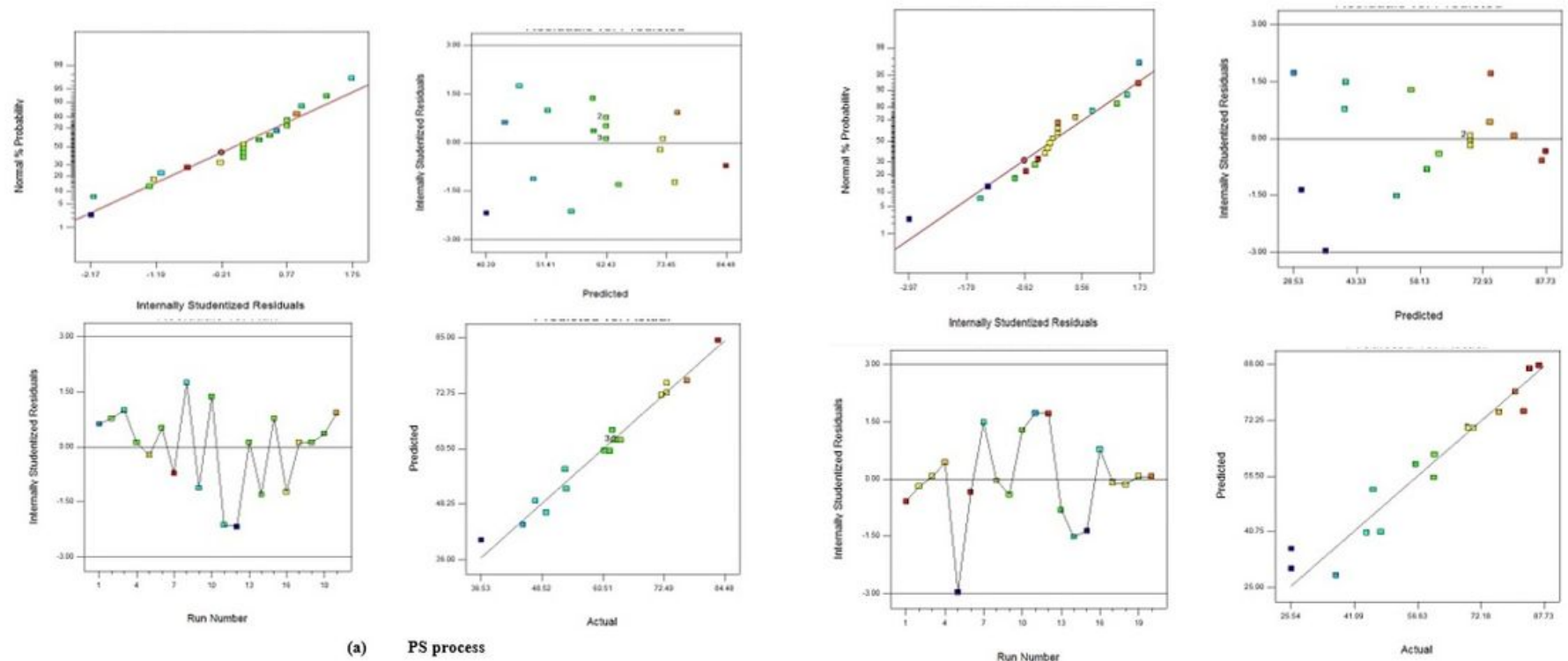

(b)

\section{Figure 7}

Adequacy diagnostic plots of normal probability, Residuals versus predicted, Residuals versus run and Actual versus predicted for (a): PS process and (b) PI process.
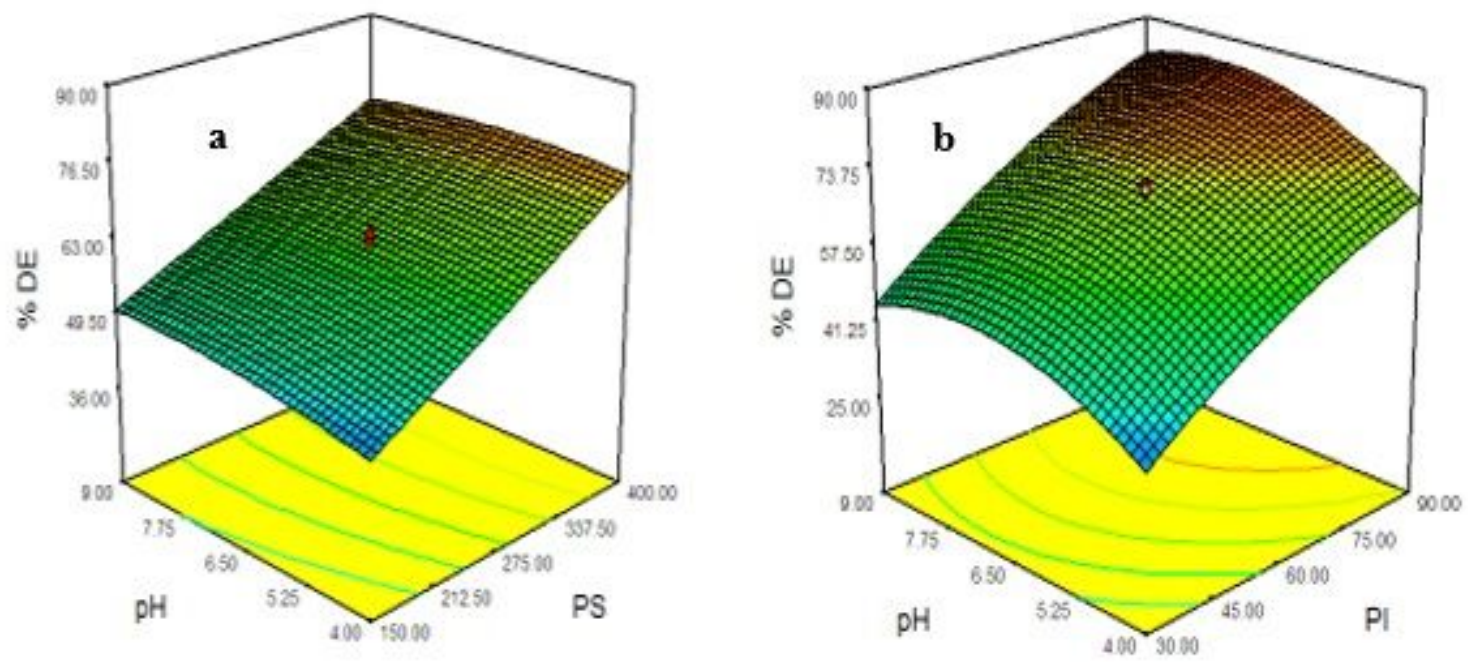

\section{Figure 8}

Response surface graphs of the variation of the DE versus: (a) the initial $\mathrm{pH}$ and the PS amount (mgL-1), (b) initial $\mathrm{pH}$ and $\mathrm{PI}$ amount (mgL-1) $\left([\mathrm{PQ}]=30 \mathrm{mgL}-1\right.$ and $\left.\mathrm{T}=25^{\circ} \mathrm{C}\right)$ 

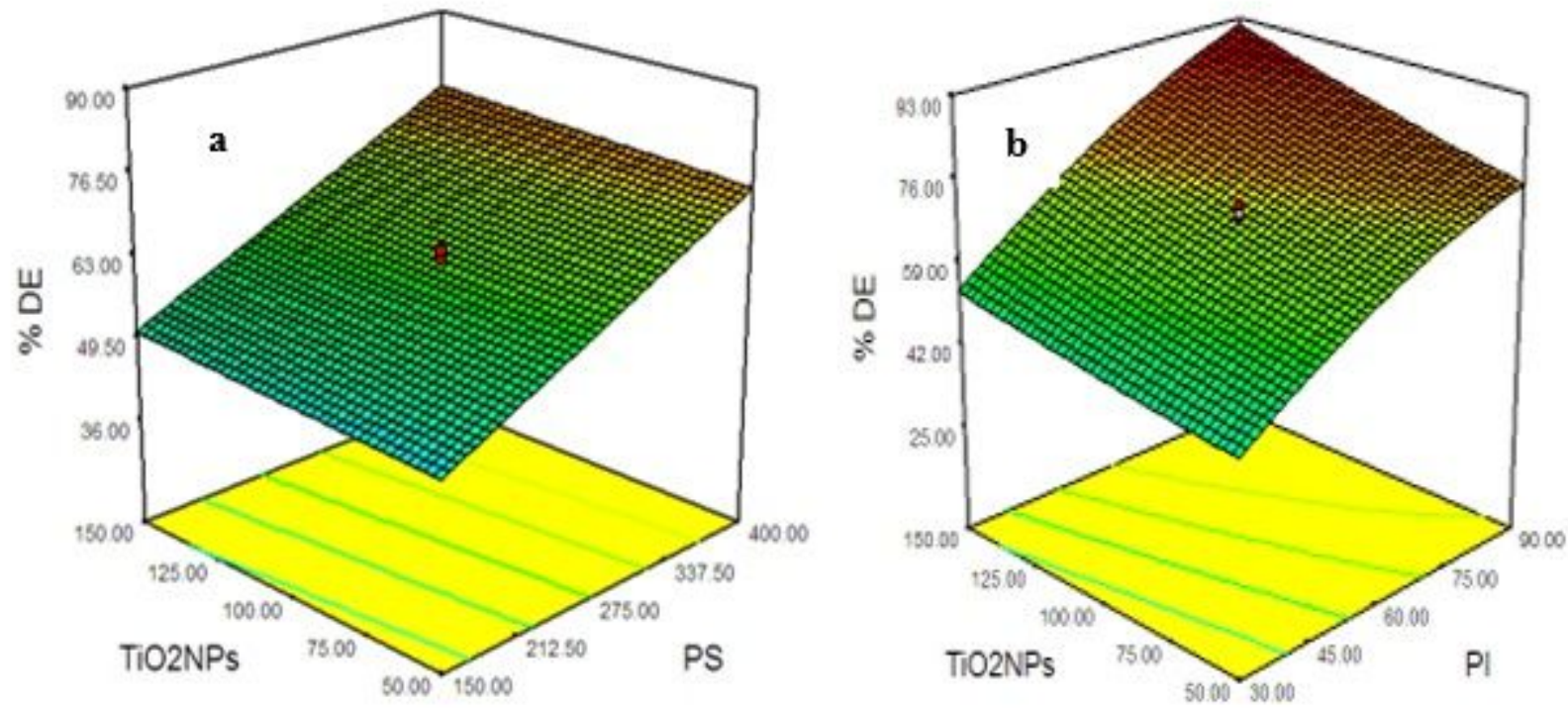

Figure 9

Response surface graph of the variation of the DE versus: (a) the initial $\mathrm{pH}$ and the PS amount, (b) initial $\mathrm{pH}$ and $\mathrm{PI}$ amount $\left([\mathrm{PQ}]=30 \mathrm{mgL}-1\right.$ and $\left.\mathrm{T}=25^{\circ} \mathrm{C}\right)$

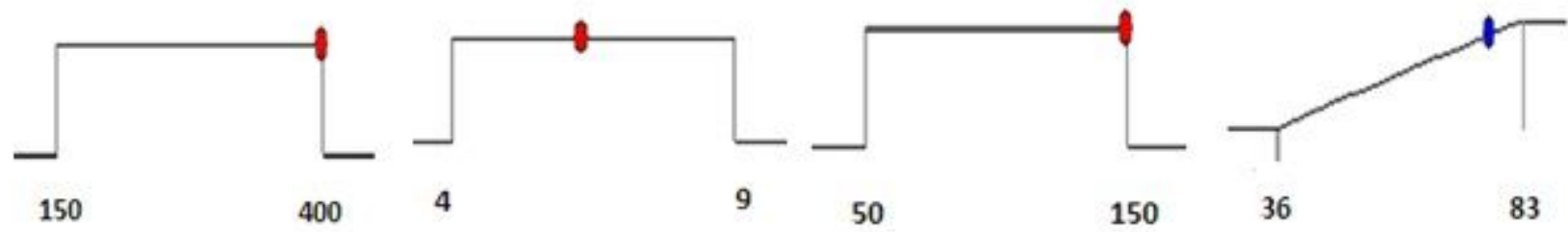

$[\mathrm{PS}]=400 \mathrm{mgL}^{-1}$

$\mathrm{pH}=6.3$

$\left[\mathrm{TiO}_{2} \mathrm{NP}\right]=150 \mathrm{mgL}^{-1}$

$\% \mathrm{DE}=77$

Figure 10

Desirability ramp for the numerical optimization for PS process

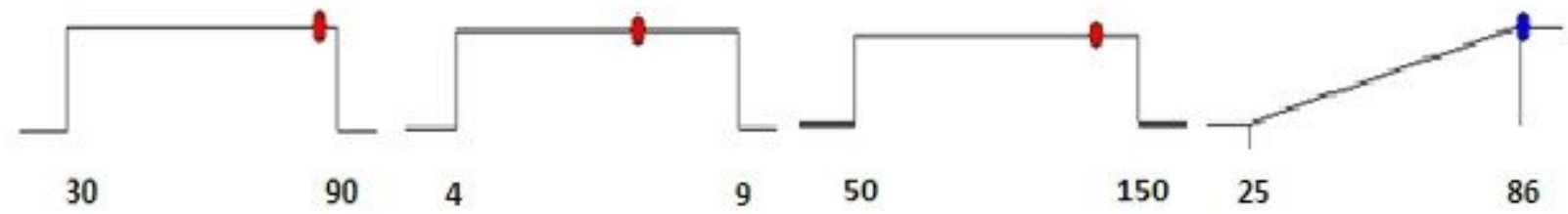

$[\mathrm{PI}]=88 \mathrm{mgL}^{-1}$

$\mathrm{pH}=7.5$

$\left[\mathrm{TiO}_{2} \mathrm{NP}\right]=125 \mathrm{mgL}^{-1}$

$\% \mathrm{DE}=86$ 
Desirability ramp for the numerical optimization for PI process
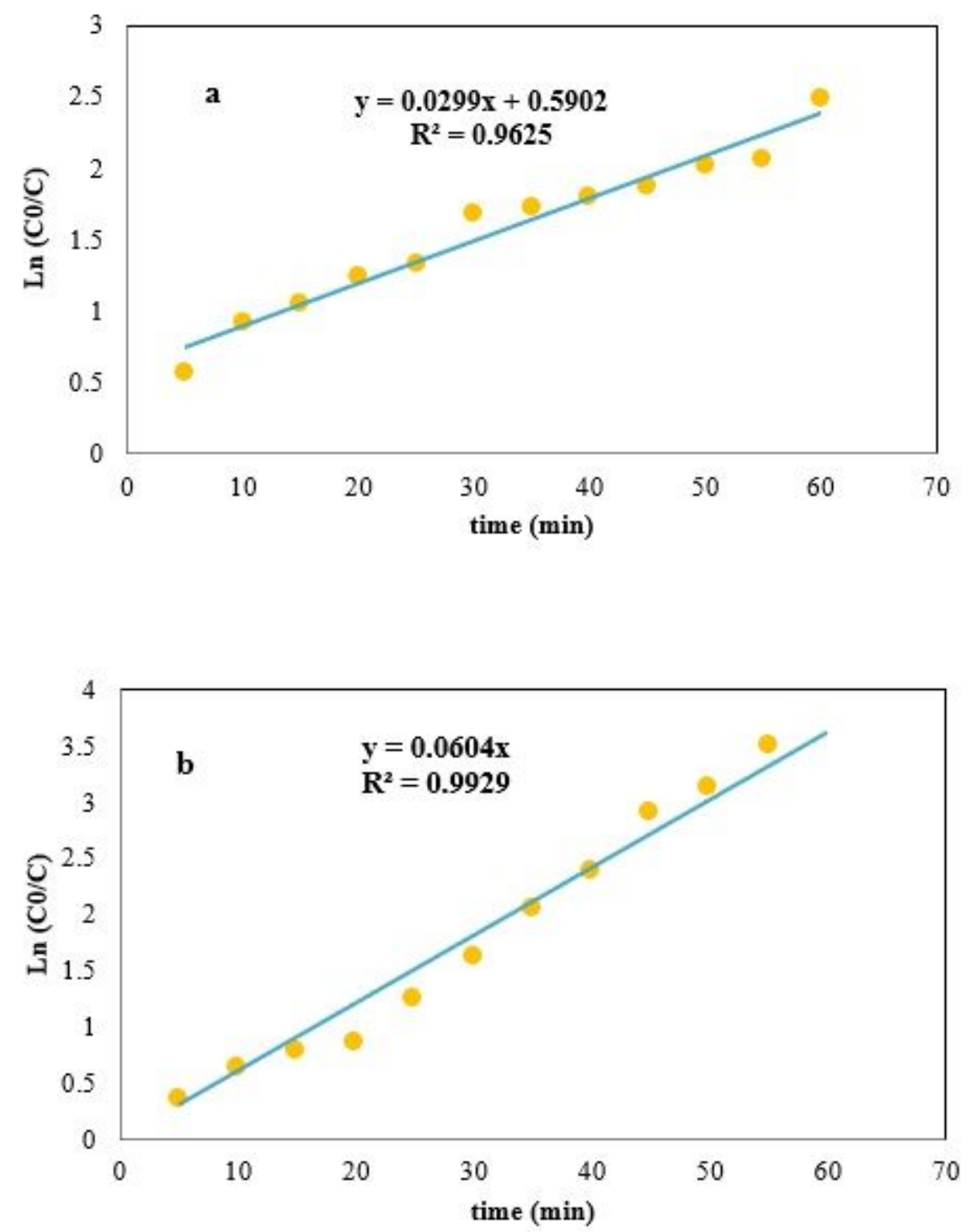

Figure 12

linear fitting of first order kinetic model for the $P Q$ degradation ( $P Q=30 \mathrm{mg} \mathrm{L}-1$ and $\left.T=25^{\circ} \mathrm{C}\right)$ a) $P S$ and b) PI process

\section{Supplementary Files}

This is a list of supplementary files associated with this preprint. Click to download.

- Supplementarylnformation.docx 